\title{
FORANE (COMPOUND 469): CROSS-OVER COMPARISON \\ WITH ENFLURANE (ETHRANE) *, HALOTHANE, AND METHOXYFLURANE IN DOGS $\dagger$
}

\author{
Peter H. Byles, M.B., B.S., Allen B. Dobkin, M.D., \\ J. Howard Ferguson, M.D. and Ashley A. Levy, Ph.D. +
}

Compound 469, now named Forane, is an analogue of enflurane (Ethrane) and is a stable, non-explosive, halogenated ether with the structure: $\mathrm{CHF}_{2}-\mathrm{O}-\mathrm{CHCl}$ $\mathrm{CF}_{3}$, i.e., 1-chloro-2,2,2-trifluorethyl difluoromethyl ether.

Preliminary small animal work with specially bred mice, rats, New Zealand rabbits, Beagle dogs, and Rhesus monkeys having shown it to be an effective general inhalational anaesthetic relatively free from significant effect on vital organs, even after prolonged anaesthesia, ${ }^{1}$ the present study was undertaken to compare its physiological and biochemical effects with those of its analogue, enflurane, and of the well established agents, halothane and methoxyflurane.

\section{Materials ANd METhods}

Twelve healthy, large, mongrel dogs, weighing between 17 and $29 \mathrm{~kg}$, were divided into four groups of three. Each group of dogs, after fasting overnight, received each of the four anaesthetics for two hours, sequentially at two-to-threeweek intervals. The groups entered the agent sequence at different points, thus following a latin-square cross-over plan (see Figure 1).

Between tests, the animals were fed a high-protein diet and were kept fit. The anaesthetic agents were administered in oxygen, and the concentrations used were approximately twice the 'minimum alveolar concentration' values² (see Figure 2).

After drawing control venous blood samples, anaesthesia was induced with intravenous thiopentone, $20 \mathrm{mg} / \mathrm{kg}$ body weight. The dogs' tracheas were then intubated and plastic cannulae were placed in the femoral arteries. After control arterial blood samples had been drawn, the cannulae were connected to Statham strain gauge pressure transducers, lead II ECG electrodes were attached, and control records of blood pressure and ECG were made on a Grass six-channel polygraph. The endotracheal tubes were then connected through Fink non-rebreathing valves to modified Harvard animal ventilators, set to deliver a minute volume to each dog of $250 \mathrm{ml} / \mathrm{kg}$ body weight of oxygen plus the appropriate anaesthetic vapour concentration. The methoxyflurane was vapourised from a Pentec vapouriser, while the other agents were placed in Fluotec ${ }^{\circledR}$ vapourisers calibrated for the

*Trademark of Ohio Medical Products, Division of Air Reduction Co, Inc, Murray Hill, N.J.

†This work was supported in part by the Division of Research Facilities and Resources of NIH through grant FR 00353 and by the Ohio Medical Products Division of Air Reduction Co, Inc, Madison, Wisconsin.

fFrom the Department of Anesthesiology and Department of Pathology, State University of New York, Upstate Medical Center, Syracuse, New York, 13210, U.S.A. 


\section{METHOXYFLURANE}

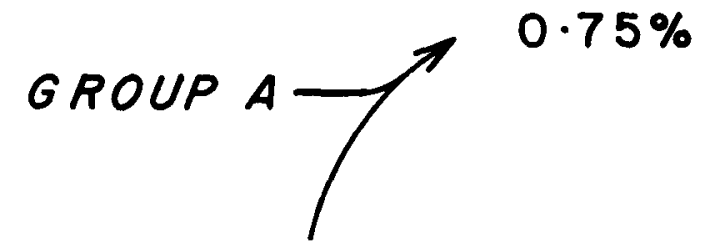

ËTHRANE

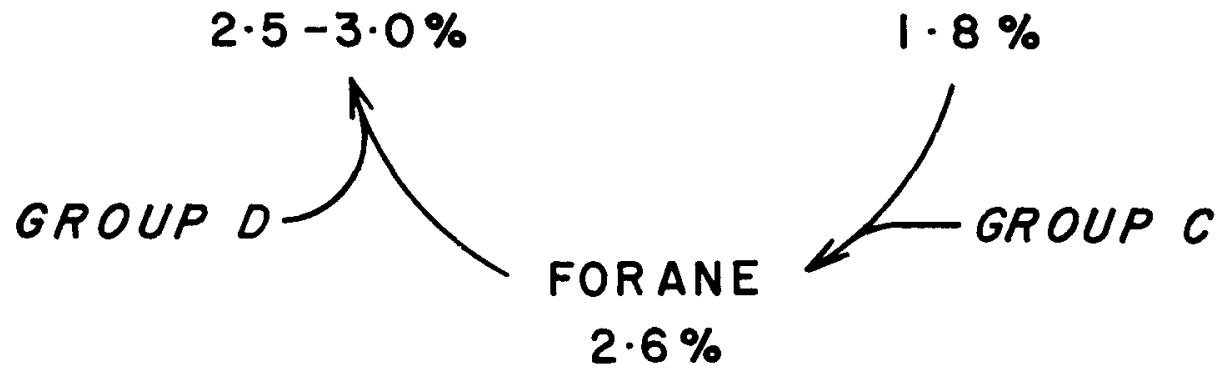

Figure 1. Latin-square cross-over plan for comparing Forane, enflurane (Ethrane), halothane and methoxyflurane, using 12 large dogs divided into 4 groups of 3 dogs.

agent in use. The concentrations delivered to the dogs were monitored by roomtemperature gas chromatography, using a Mayo analyser. Urine output was collected by catheter, and sufficient balanced electrolyte solution (Normosol R) was infused intravenously to replace the volume of blood samples taken and to maintain fluid balance. Deep anaesthesia was continued for two hours with recording of blood pressure and ECG every ten minutes, and further arterial and venous blood samples were drawn at the mid-point and end of each experiment. Thus each dog had two hours of each of four halogenated anaesthetics within eight weeks. At the end of the last anaesthetic, the liver and kidneys were removed for pathological cxamination.

The arterial anaerobic blood samples were analyzed for $\mathrm{pH}, \mathrm{Pco}_{2}$, and $\mathrm{Po}_{2}$ on an Instrumentation Laboratories blood gas analyser. Haematocrit, haemoglobin concentrations. and oxygen saturation were determined on the same samples. Lactate and pyruvate levels ${ }^{3}$ were measured on aerobic free-flowing arterial blood samples and the lactate/pyruvate ratio and excess lactate were calculated. The venous blood samples were analysed for the variables listed in the tables below, employing standard laboratory methods which we have described in a previous communication. ${ }^{4}$ Non-esterified fatty acids (free fatty acids) were determined by a titration method and blood insulins were done by a radio-immuno-assay technique. ${ }^{5.6}$

\section{Results}

\section{Clinical observations}

After induction with thiopentone, intubation, and arranging monitoring devices, the administration of the inhalation anaesthetics to these animals was very smooth 


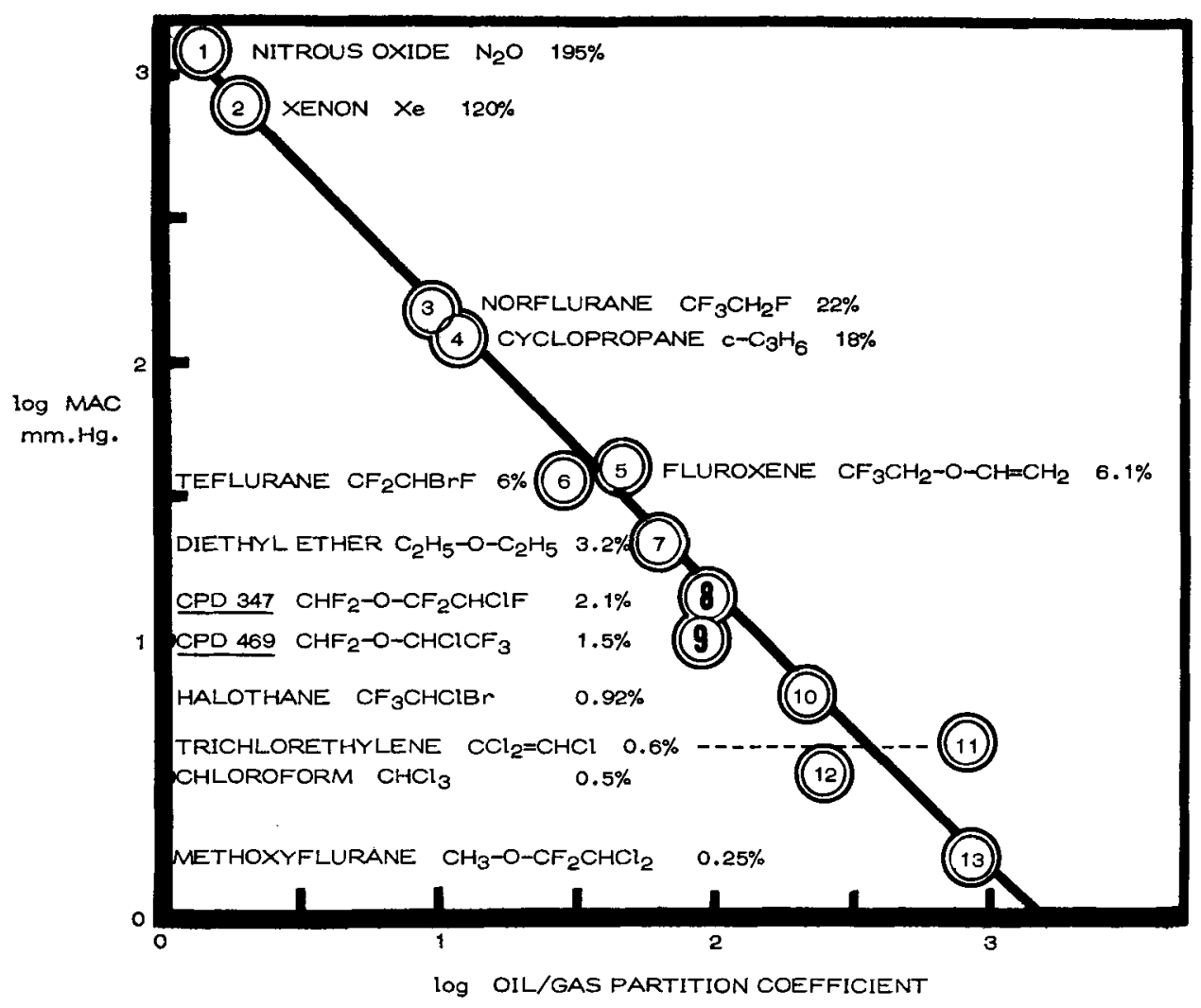

Figure 2. Indicates the approximate minimum inhaled (alveolar) concentration required to permit surgical incision without pain or movement in 50 per cent of subjects (man). (Diagram slightly modified from Saidman et al., Ref. 2.) The position of the new compounds, enflurane ( $\vec{E}$ thrane, Compound 347) and Forane (Compound 469) are shown as (B) and (9) on the graph. Note that the anaesthetic potency of these 2 compounds is therefore between that of diethyl ether and halothane. This graph of course does not indicate the rates of uptake, induction and emergence from anaesthesia with these agents.

in all respects. None of the animals bucked, salivated, or hiccuped during introduction of the maintenance agent. The animals often twitched during administration of anaesthesia with enflurane. Pulmonary ventilation with the mechanical pump was accepted by each animal with each anaesthetic without clinical evidence of changes in pulmonary compliance and the concentrations of the inhalation agents delivered appeared to provide conditions that would be appropriate for surgical anaesthesia. Urine output usually exceeded $50 \mathrm{ml}$ with each agent. It was apparent that, while these dogs were hyperventilated with approximately 0.75 per cent methoxyflurane, 1.8 per cent halothane, 2.6 per cent Forane or 3 per cent enflurane, smooth anaesthetic conditions and cardiovascular stability could be maintained. Recovery to the point of steady walking after thiopentone induction and 2 hours of inhalation anaesthesia took less than 1 hour with enflurane (48 \pm 9 $\min ), 1$ to $1^{1 / 2}$ hours with Forane $(77 \pm 19 \mathrm{~min})$, and $1 \frac{1}{2}$ to 2 hours with halothane $(88 \pm 27 \mathrm{~min}$ ) and methoxyflurane $(108 \pm 30 \mathrm{~min})$ respectively (mean values of 11 administrations of each agent). 


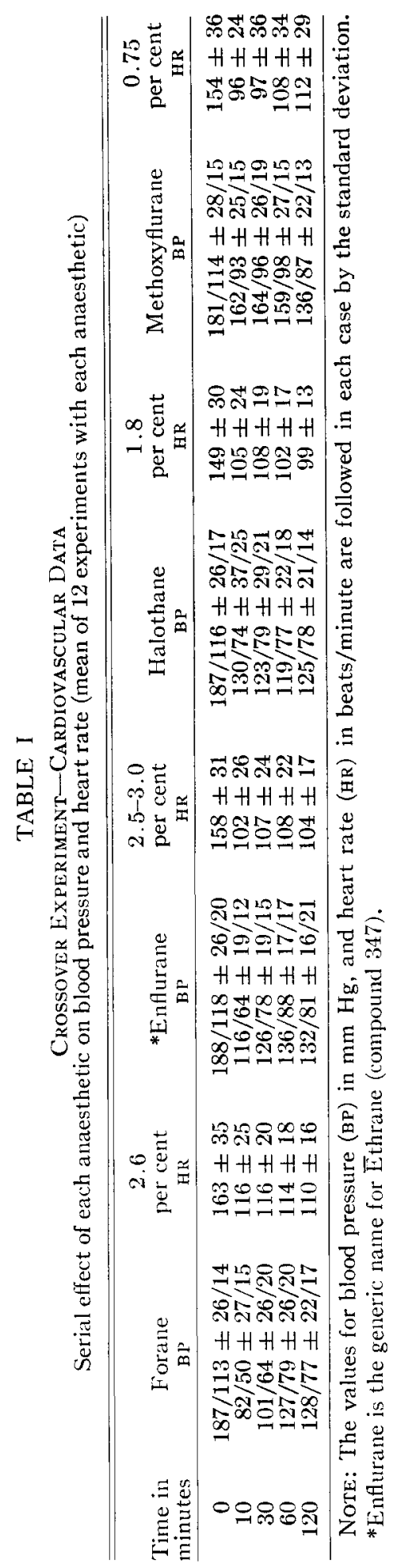




\section{Cardiovascular data (Table I)}

All the dogs had an initial elevation of arterial blood pressure and heart rate due to the stimuli of intubation and arterial cannulation under thiopentone anaesthesia. A sharp fall in each occurred during the first ten minutes of monitoring during inhalation anaesthesia, the initial blood pressure fall being greatest with Forane and least with methoxyflurane, due to the marked differences in the solubility rate and of uptake of the agents in the blood. Over the subsequent 110 minutes, the blood pressure readings converged and stabilized at normal levels without significant differences between the four anaesthetic agents. The mean blood pressures at the end of the 2-hour tests were 94, 98, 94, and $104 \mathrm{~mm} \mathrm{Hg}$ for Forane, enflurane, halothane, and methoxyflurane respectively. The pulse pressures were, in general, proportional to the mean blood pressures. The heart rates showed a similar convergence and stabilized at between 90 and 110 per minute with all agents, the rate with halothane being the lowest and the rate with methoxyflurane the highest. No significant electrocardiographic abnormalities were seen in any of the dogs.

\section{Acid-base data (Table II)}

All the dogs started with a slight metabolic acidosis of about $2.5 \mathrm{mEq} / \mathrm{L}$ base because they had been fasting for about 12 hours. During the course of the experiments, they developed mild respiratory alkalosis due to the mechanical ventilation. There were only slight changes in the metabolic element and differences between agents were insignificant. The haemoglobin and haematocrit values tended to fall, probably due largely to the amount of blood drawn for biochemical assays and the haemodiluting effect of the intravenous infusion.

Electrolyte data (Table III)

The serum sodium, calcium, and magnesium levels showed small changes which were not clinically significant. Serum potassium fell about $0.3 \mathrm{mEq} / \mathrm{L}$ during the

TABLE II

Crossover Experiment: Acid-Base Data. Serial Effect of each Anaesthetic on pH, Haemoglobin, Haematocrit and Blood Gases (Acid-Base Balance)-(Mean of 12 EXPeriMENTS WITH EACH ANAESTHETIC)

\begin{tabular}{|c|c|c|c|c|c|}
\hline & $\mathrm{pH}$ & $\underset{\text { torr }}{\mathrm{PaCO}_{2}}$ & $\begin{array}{l}\mathrm{PaO}_{2} \\
\text { torr }\end{array}$ & $\begin{array}{c}\text { Hct } \\
\text { per cent }\end{array}$ & $\begin{array}{c}\text { Hgb Grams } \\
\text { per cent }\end{array}$ \\
\hline $\begin{array}{l}\text { Compound } \\
469\end{array}$ & $\begin{array}{l}\text { a } 7.380 \pm 0.113 \\
\text { b } 7.412 \pm 0.108 \\
\text { c } 7.405 \pm 0.045\end{array}$ & $\begin{array}{l}39.1 \pm 4.6 \\
34.5 \pm 4.3 \\
36.5 \pm 5.5\end{array}$ & $\begin{array}{c}68.2 \pm 8.1 \\
390 \pm 142 \\
547 \pm 73\end{array}$ & $\begin{array}{l}42.0 \pm 3.3 \\
36.7 \pm 2.9 \\
36.1 \pm 3.9\end{array}$ & $\begin{array}{l}15.5 \pm 1.3 \\
13.8 \pm 1.2 \\
13.4 \pm 1.7\end{array}$ \\
\hline Enflurane & $\begin{array}{l}\text { a } 7.384 \pm 0.056 \\
\text { b } 7.439 \pm 0.098 \\
\text { c } 7.429 \pm 0.098\end{array}$ & $\begin{array}{l}36.6 \pm 4.2 \\
31.0 \pm 7.3 \\
34.2 \pm 7.2\end{array}$ & $\begin{array}{l}73.8 \pm 14.2 \\
428 \pm 153 \\
574 \pm 83\end{array}$ & $\begin{array}{l}43.9 \pm 3.6 \\
39.9 \pm 3.7 \\
40.2 \pm 2.9\end{array}$ & $\begin{array}{l}17.0 \pm 2.6 \\
16.1 \pm 2.3 \\
16.1 \pm 2.3\end{array}$ \\
\hline Halothane & $\begin{array}{l}\text { a } 7.40 \pm 0.119 \\
\text { b } 7.42 \pm 0.03 \\
\text { c } 7.414 \pm 0.065\end{array}$ & $\begin{array}{l}34.2 \pm 5.6 \\
30.8 \pm 3.6 \\
30.4 \pm 2.4\end{array}$ & $\begin{array}{l}74.4 \pm 11.8 \\
543 \pm 29 \\
580 \pm 99\end{array}$ & $\begin{array}{l}42.5 \pm 3.3 \\
37.2 \pm 2.5 \\
36.2 \pm 3.0\end{array}$ & $\begin{array}{l}17.0 \pm 2.8 \\
14.5 \pm 1.6 \\
14.0 \pm 1.6\end{array}$ \\
\hline $\begin{array}{l}\text { Methoxy- } \\
\text { flurane }\end{array}$ & $\begin{array}{l}\text { a } 7.378 \pm 0.047 \\
\text { b } 7.434 \pm 0.080 \\
\text { c } 7.423 \pm 0.086\end{array}$ & $\begin{array}{l}37.2 \pm 3.7 \\
33.2 \pm 5.2 \\
32.0 \pm 5.2\end{array}$ & $\begin{array}{c}69.1 \pm 6.3 \\
473 \pm 135 \\
551 \pm 81\end{array}$ & $\begin{array}{l}43.8 \pm 3.6 \\
40.0 \pm 4.2 \\
38.8 \pm 3.6\end{array}$ & $\begin{array}{l}18.3 \pm 3.0 \\
17.0 \pm 3.1 \\
16.3 \pm 3.1\end{array}$ \\
\hline
\end{tabular}

$\mathrm{a}=\operatorname{start} \quad \mathrm{b}=$ middle $\mathrm{c}=$ end 
TABLE III

Crossover Experiment: Electrolyte Data. Serial Effect of each Anaesthetic on Plasma Electrolytes-(Mean of 12 Experiments With each ANAESTHETIC)

\begin{tabular}{|c|c|c|c|c|}
\hline & $\begin{array}{c}\text { Potassium } \\
\mathrm{mEq} / \mathrm{L}\end{array}$ & $\begin{array}{l}\text { Sodium } \\
\mathrm{mEq} / \mathrm{L}\end{array}$ & $\begin{array}{c}\text { Magnesium } \\
\mathrm{mEq} / \mathrm{L}\end{array}$ & $\begin{array}{c}\text { Calcium } \\
\mathrm{mg} / 100 \mathrm{ml}\end{array}$ \\
\hline $\begin{array}{l}\text { Compound } \\
469\end{array}$ & $\begin{array}{l}\text { a } 3.94 \pm 0.28 \\
\text { b } 3.60 \pm 0.44 \\
\text { c } 3.81 \pm 0.27\end{array}$ & $\begin{array}{l}143 \pm 5.4 \\
140 \pm 15.9 \\
145 \pm 4.7\end{array}$ & $\begin{array}{l}1.32 \pm 0.57 \\
1.52 \pm 0.32 \\
1.51 \pm 0.37\end{array}$ & $\begin{array}{l}5.10 \pm 0.19 \\
5.01 \pm 0.27 \\
4.91 \pm 0.21\end{array}$ \\
\hline Enflurane & $\begin{array}{l}\text { a } 4.25 \pm 0.53 \\
\text { b } 3.85 \pm 0.30 \\
\text { c } 3.96 \pm 0.80\end{array}$ & $\begin{array}{l}158 \pm 21.6 \\
151 \pm 12.3 \\
160 \pm 29.6\end{array}$ & $\begin{array}{l}1.26 \pm 0.47 \\
1.35 \pm 0.41 \\
1.41 \pm 0.56\end{array}$ & $\begin{array}{l}4.99 \pm 0.57 \\
5.22 \pm 0.25 \\
5.01 \pm 0.40\end{array}$ \\
\hline Halothane & $\begin{array}{l}\text { a } 3.92 \pm 0.28 \\
\text { b } 3.63 \pm 0.36 \\
\text { c } 3.51 \pm 0.28\end{array}$ & $\begin{array}{l}144 \pm 4.6 \\
143 \pm 10.9 \\
142 \pm 6.1\end{array}$ & $\begin{array}{l}1.29 \pm 0.27 \\
1.43 \pm 0.40 \\
1.42 \pm 0.32\end{array}$ & $\begin{array}{l}5.09 \pm 0.34 \\
5.02 \pm 0.20 \\
4.68 \pm 1.37\end{array}$ \\
\hline $\begin{array}{l}\text { Methoxy- } \\
\text { flurane }\end{array}$ & $\begin{array}{l}\text { a } 4.02 \pm 0.43 \\
\text { b } 3.78 \pm 0.36 \\
\text { c } 3.56 \pm 0.36\end{array}$ & $\begin{array}{l}148 \pm 5.8 \\
154 \pm 17.7 \\
148 \pm 13.5\end{array}$ & $\begin{array}{l}1.42 \pm 0.29 \\
1.30 \pm 0.36 \\
1.51 \pm 0.34\end{array}$ & $\begin{array}{l}5.23 \pm 0.28 \\
5.13 \pm 0.27 \\
5.16 \pm 0.33\end{array}$ \\
\hline
\end{tabular}

first hour with all agents, and was variable thereafter, without leaving the normal range.

\section{Blood chemistry data (Tabe IV)}

There was no appreciable change from the normal range in the BuN, creatine, transaminases, or bilirubin with any of the anaesthetics. Blood sugar tended to rise slightly with all agents.

The plasma proteins fell slightly without significant differences between agents and without change in $\mathrm{A} / \mathrm{G}$ ratio, probably due to haemodilution and blood sample loss. The free fatty acids fell by about 50 per cent during the first hour and then remained stable with all agents. The initial FFA (non-esterified fatty acids) values were elevated because the animals were in a fasting state and were under stress (tense) during initial sampling of blood. The lowered levels during anaesthesia probably reflect a normal functioning liver. Changes in alkaline phophatase and prothrombin time were small and probably insignificant (see Table V). Lactate, pyruvate, $\mathrm{L} / \mathrm{P}$ rates, and excess lactate changed slightly (Table VI). The alterations observed with halothane and methoxyflurane were in the range reported previously in similar experiments. ${ }^{4}$

\section{Endocrine data}

In all cases, the levels of endocrine substances measured remained within the rather tentative normal ranges currently accepted, with the exception of plasma cortisol, which rose in every case, presumably due to stress. Forane showed no tendency to raise the plasma catecholamine levels in these dogs (Table VII).

\section{Pathological examinations}

There were no gross pathological abnormalities in the liver and kidneys among these dogs, i.e., by direct inspection and cut sections there was no evidence of lipidosis (presence of visible fats within the hepatic and renal structure - which is 


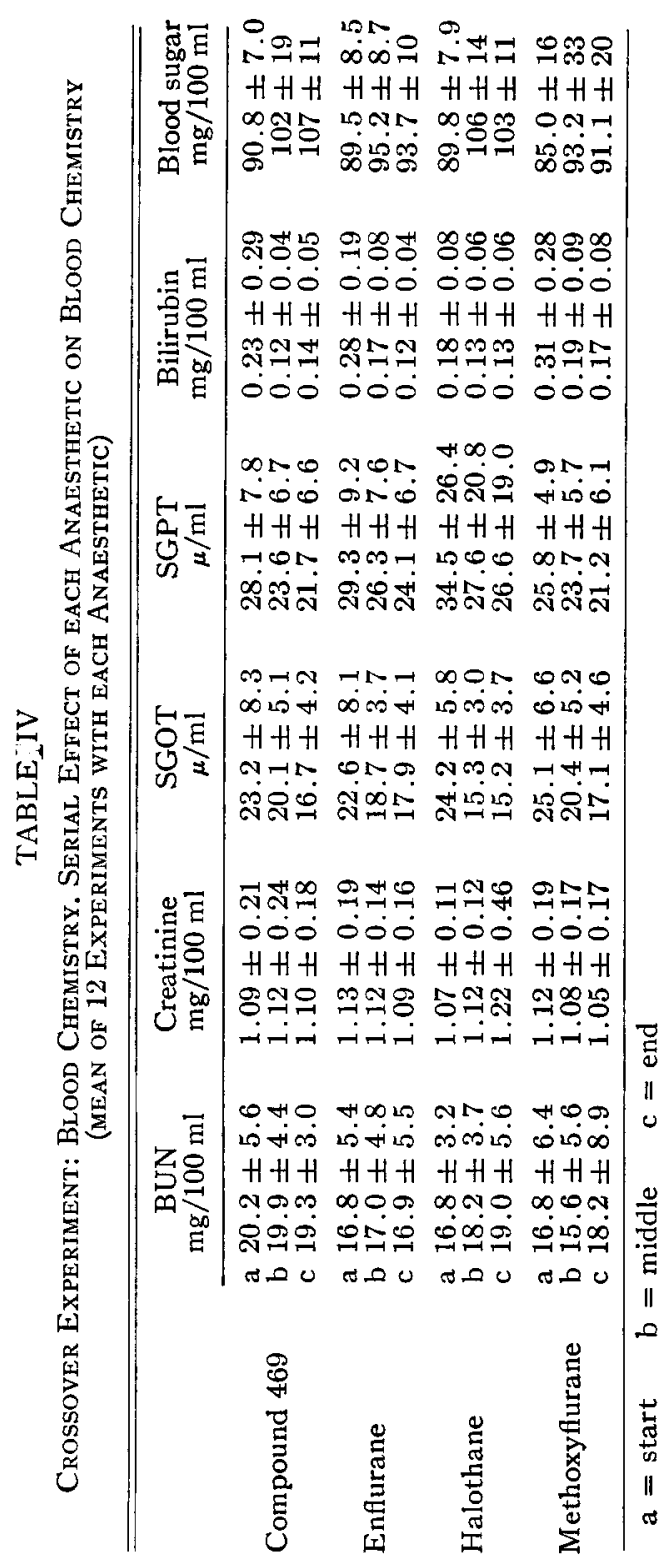




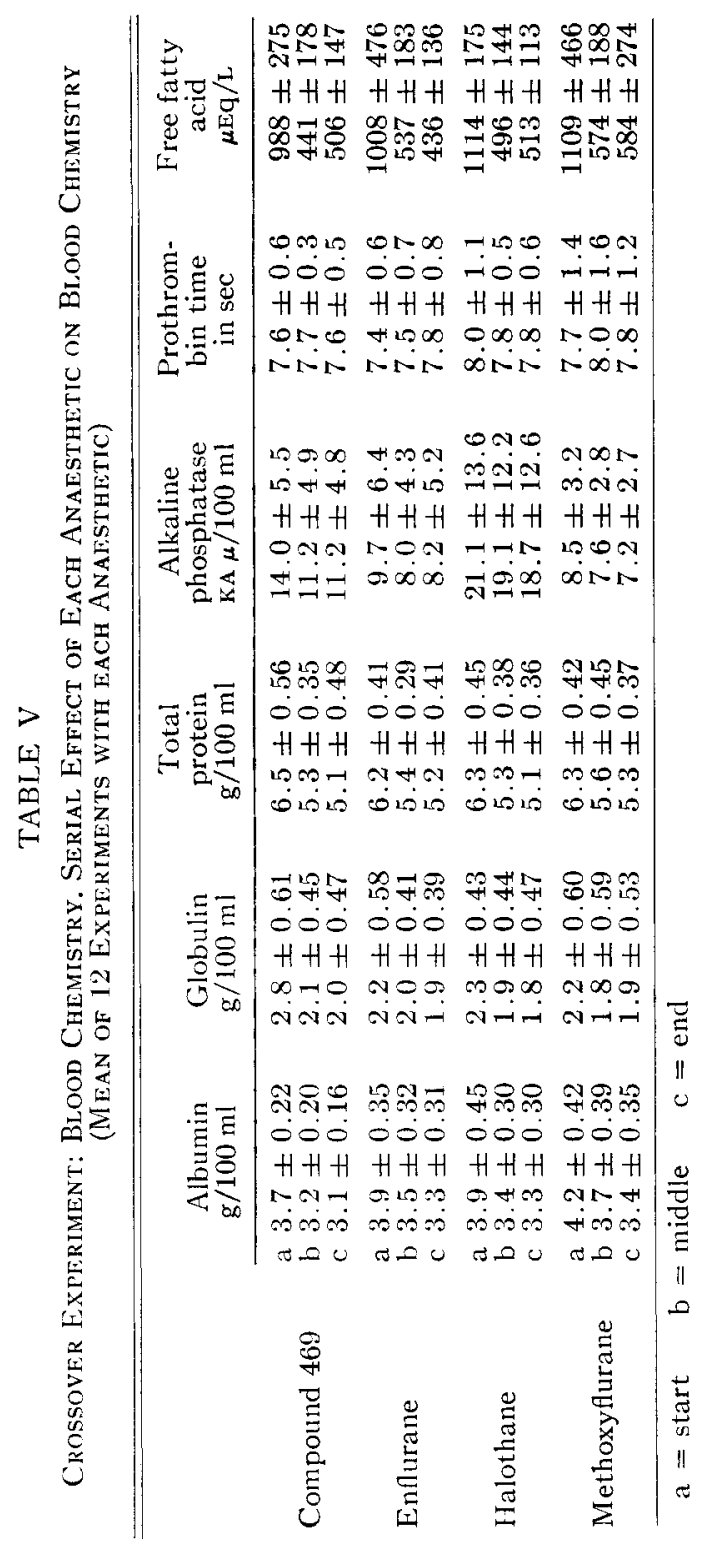


TABLE VI

\begin{tabular}{|c|c|c|c|c|}
\hline & $\begin{array}{l}\text { Lactate } \\
\mathrm{mM} / \mathrm{L}\end{array}$ & $\begin{array}{c}\text { Pyruvate } \\
\mathrm{mM} / \mathrm{L}\end{array}$ & L/P Ratio & $\begin{array}{l}\text { Excess } \\
\text { lactate } \\
\mathrm{mu} / \mathrm{L}\end{array}$ \\
\hline $\begin{array}{l}\text { Compound } \\
469\end{array}$ & $\begin{array}{l}\text { a } 1.26 \pm 0.41 \\
\text { b } 2.00 \pm 0.40 \\
\text { c } 1.78 \pm 0.50\end{array}$ & $\begin{array}{l}0.128 \pm 0.027 \\
0.164 \pm 0.062 \\
0.163 \pm 0.032\end{array}$ & $\begin{array}{r}9.88 \\
12.19 \\
10.91\end{array}$ & $\begin{array}{l}0.38 \\
0.17\end{array}$ \\
\hline Enflurane & $\begin{array}{ll}\text { a } & 0.96 \pm 0.36 \\
\text { b } & 1.78 \pm 0.66 \\
\text { c } & 1.59 \pm 0.82\end{array}$ & $\begin{array}{l}0.130 \pm 0.043 \\
0.180 \pm 0.060 \\
0.150 \pm 0.049\end{array}$ & $\begin{array}{r}7.37 \\
9.90 \\
10.58\end{array}$ & $\begin{array}{l}0.46 \\
0.48\end{array}$ \\
\hline Halothane & $\begin{array}{l}\text { a } 1.07 \pm 0.74 \\
\text { b } 2.04 \pm 0.82 \\
\text { c } 1.92 \pm 0.61\end{array}$ & $\begin{array}{l}0.197 \pm 0.248 \\
0.182 \pm 0.045 \\
0.154 \pm 0.050\end{array}$ & $\begin{array}{r}5.44 \\
11.24 \\
12.45\end{array}$ & $\begin{array}{l}1.06 \\
1.08\end{array}$ \\
\hline $\begin{array}{l}\text { Methoxy- } \\
\text { flurane }\end{array}$ & $\begin{array}{l}\text { a } 1.06 \pm 0.44 \\
\text { b } 2.21 \pm 1.23 \\
\text { c } 2.40 \pm 1.16\end{array}$ & $\begin{array}{l}0.117 \pm 0.048 \\
0.193 \pm 0.068 \\
0.204 \pm 0.067\end{array}$ & $\begin{array}{r}9.05 \\
11.45 \\
11.75\end{array}$ & $\begin{array}{l}0.46 \\
0 . \tilde{5} 5\end{array}$ \\
\hline
\end{tabular}

$\mathrm{a}=\mathrm{start} \quad \mathrm{b}=$ middle $\quad \mathrm{c}=\mathrm{end}$

usually abnormal and may be a degenerative change). Microscopic examination of permanent sections of these tissues stained with Sudan Iv and with haematoxolin/ eosin showed variable fatty infiltration in both organs in all animals. Such fatty infltration may be physiological in normal animals on fattening rations or during and following pregnancy. It may also accumulate as a result of bacterial toxins, organic or inorganic poisons, chronic infection, metabolic diseases, anaemia, and bouts of hypoxia of liver cells. In this case, the fatty infiltration was probably a change due to the repeated deep anaesthetics. Since the transaminases remained below 35 units in all the animals, it is highly improbable that degenerative or necrotic changes were likely to occur. Since this experiment was a severe test, some effect on the liver or kidney by these agents is not surprising.

\section{Conclusrons}

These studies indicated that Forane (Compound 469), which has chemical properties very similar to enflurane (Ethrane), is an effective, safe anaesthetic. The anaesthetic properties were a little more potent than enflurane but less potent than methoxyflurane. It is a slightly weaker hypnotic than halothane. Recovery from Forane is rapid without evident effects on vital functions or on biochemical tests in dogs. This new anaesthetic agent would probably be safe in humans and might offer advantages over currently used halogenated anaesthetic compounds due to its rapid action.

\section{SUMMARY}

Forane (Compound 469) is a stable, non-explosive, halogenated ether compound similar in structure to enflurane (Ethrane). We found that it had effective and safe anaesthetic properties when tested in small, purebred animals (mice, rats, rabbits, beagle dogs, and rhesus monkeys ).

This study was undertaken to compare the effects of a vapour concentration of 2 MAC of Forane in oxygen, after thiopentone induction, with those of enflurane, 


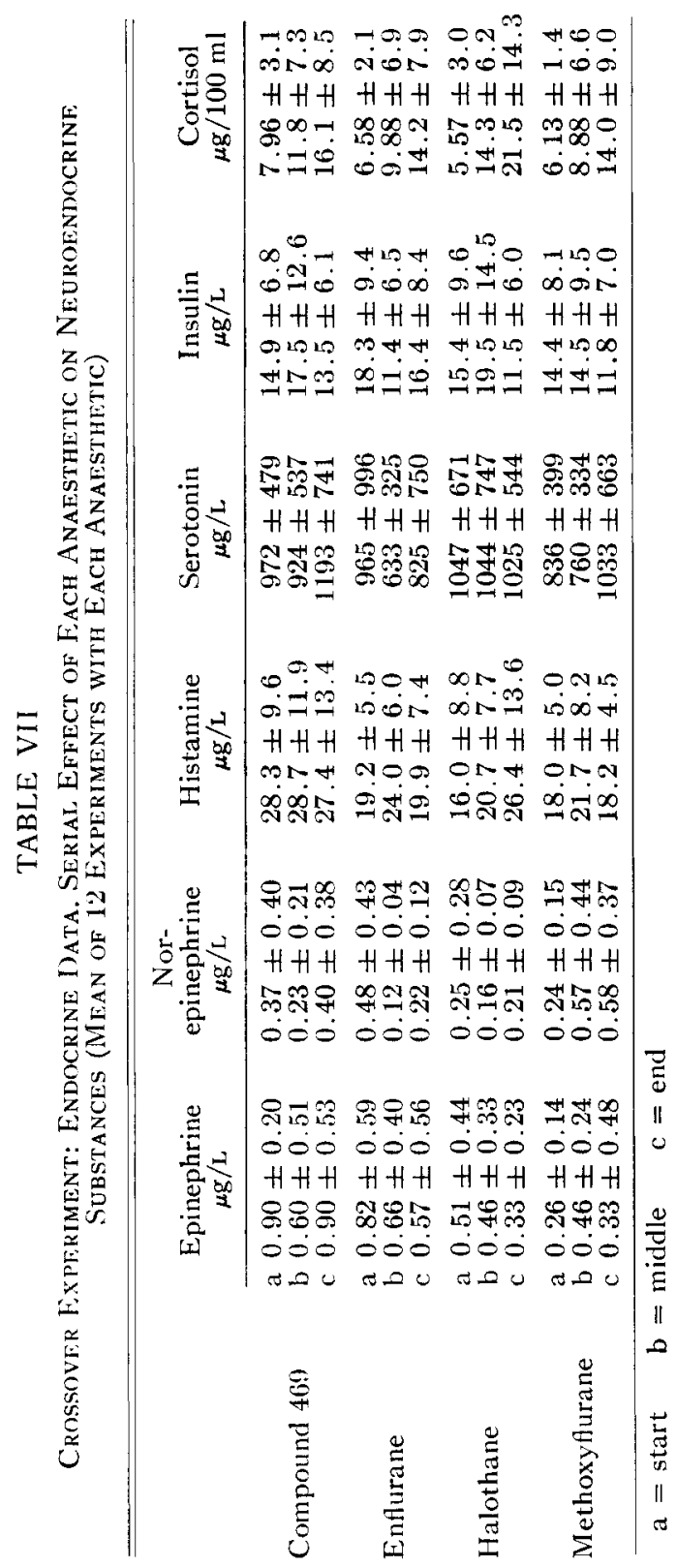


halothane, and methoxyflurane on vital functions and biochemical blood tests, employing a cross-over experiment in 12 large, healthy, mongrel dogs.

The clinical observations showed that Forane is an effective anaesthetic that acts rapidly, does not provoke cardiac ventricular arrhythmias, neuromuscular disturbances, or airway secretions. Recovery is rapid and smooth. Aside from a moderate elevation of blood sugar and plasma cortisol and reduction of free fatty acids, as seen with the other halogenated anaesthetics, no significant changes in the blood chemistries, electrolytes, or acid-base balance occurred. This study indicated that Forane would be useful and safe for humans.

\section{RÉSUMÉ}

Forane est un éther halogéné stable, non-explosif, d'une structure ressemblant à celle de l'enflurane (E thrane). Nous avons constaté que le Forane est doué de qualités anesthésiques efficaces et sûres chez des animaux de laboratoire de pur sang (souris, rats, lapins, bigles, et singes rhésus).

Ce travail compare les effets des vapeurs de Forane à concentration de $2 \mathrm{MAC}$ dans l'oxygène avec ceux de l'enflurane, halothane et methoxyflurane après l'induction au pentothal. Nous avons fait une série de tests croisés sur 12 gros chiens mâles métis en bonne santé dont les paramètres physiologiques et biochimiques étaient suivis.

Nos observations cliniques démontrent que le Forane possède une action rapide, ne cause pas d'arythmies ventriculaires, ni perturbations neuromusculaires ni sécrétions dans les voies respiratoires. Le réveil est rapide et doux. En dehors d'une élévation modérée du sucre sanguin, du cortisole plasmatique ainsi que d'une baisse des acides graisseux libres, vues d'ailleurs avec les autres agents halogénés, il n’y avait pas de changements significatifs de la biochimie du sang, des substances endocrines, des électrolytes ni de l'équilibre acide-base. Ce travail montre que le Forane peut être un anesthésique utile et sûr chez l'homme.

\section{ACKNOWLEDGEMENTS}

The authors are grateful to many assistants on this project. Doctor Benjamin F. Africa, Robert L. Gelder, B.S., Christina Bisset, R.N., and George Mann, R.T., in particular, rendered invaluable assistance.

\section{REFERENCES}

1. ByLes, P. H.; Dobrin, A. B.; \& Ferguson, J. H. Pharmacological and pathological effects of Compound 469. Unpublished reports fled with Air Reduction Co, Inc, (1969).

2. Saidman, L. J.; Eger, E. I., Ir; Munson, E. S.; Babad, A. B.; \& Muallem, M. Minimum alveolar concentrations of methoxyllurane, halothane, ether, and cyclopropane in man: correlation with theories of anaesthesia. Anesthesiology, 28: 994 (1967).

3. Nevirle, J. F., Jr, \& Gelder, R. L. Modified enzymatic methods for the determination of $\mathrm{L}-(+)$-lactic and pyruvic acids in blood. Amer. J. Clin. Path., 55: 152 (1971).

4. Dobkin, A. B.; Brles, P. H.; \& Neville, J. F., JR. Neuroendocrine and metabolic effects of general anaesthesia during spontaneous breathing, controlled breathing, mild hypoxia and mild hypercarbia. Canad. Anaesth. Soc. J., 13: 130 (1966).

5. DoLE, V.P. A relation between non-esterified fatty acids in plasma and the metabolism of glucose. J. Clin. Invest., 35: 150 ( 1956).

6. Morgan, C. R. \& Lazarow, A. Immunoassay of insulin: two antibody system. Diabetes, 12: 115 (1963). 